\title{
DA REDUÇÃO DA IDADE PENAL À EQUAÇÃO DO TEMPO: NOTAS CRÍTICAS CONTRA AS PROPOSTAS QUE RECHAÇAM PRINCÍPIOS CONSTITUCIONAIS
}

\author{
Sheila Daniela Medeiros de Santos*
}

RESUMO: Este artigo objetiva sinalizar as contribuiçóes teóricas do renomado pesquisador Angel Pino, as quais se fundamentam na perspectiva histórico-cultural em Psicologia, para a análise de alguns aspectos significativos que emergem dos debates travados acerca da PEC $171 / 1993$. O artigo primeiramente situa o contexto em que se inserem os embates atinentes à redução da idade penal e, na sequência, problematiza algumas das premissas que os sustentam, alinhavando os fios da trama construída à luz das produçóes teóricas basilares do pesquisador Angel Pino. Por último, tece consideraçóes sobre o tema destacando questôes nucleares e desvelando aspectos ideológicos do debate, dissimulados, sob o véu das aparências (LEFEBVRE, 1979), pelo ideário neoliberal.

Palavras-chave: Redução da idade penal. Violência. Desenvolvimento humano. Psicologia histórico-cultural.

\section{FROM LOWERING THE AGE OF CRIMINAL RESPONSIBILITY TO TIME EQUATION: CRITICAL NOTES AGAINST PROPOSALS WHICH REJECT CONSTITUTIONAL PRINCIPLES}

ABSTRACT: This article aims to signal the theoretical contributions of the renowned researcher Angel Pino, which are based on the culturalhistorical perspective in Psychology, for the analysis of some significant aspects that emerge from the discussions about the PEC 171/1993. The article first presents the context in which the debate on the reduction of the age of criminal responsibility emerges. Following, it discusses some of the assumptions that underpin them, tacking the threads of the fabric constructed in light of Angel Pino's basic theoretical productions. Finally, it reflects about the theme, highlighting nuclear questions and unveiling the ideological aspects of the debate that are hidden under the veil of appearances (LEFEBVRE, 1979), by neoliberal ideology.

Keywords: Lowering the age of criminal responsibility. Violence. Human development. Cultural-historical psychology.

\footnotetext{
* Universidade Federal de Goiás, Programa de Pós-graduação em Psicologia. Goiânia, GO., Brasil. E-mail de contato: sheiladaniela@yahoo.com.br.
} 


\section{DE LA RÉDUCTION DE LA MAJORITE PENALE A L'EQUATION DU TEMPS: NOTES CRITIQUES CONTRE LES PROPOSÉES REJETTANT LES PRINCIPES CONSTITUTIONNELS}

RÉSUMÉ: Cet article vise à signaler les contributions théoriques du renommé chercheur Angel Pino, qui sont fondées sur la perspective historique et culturelle en psychologie à l'analyse de certains aspects importants qui ressortent des discussions sur la PEC 171/1993. L'article situe d'abord le contexte dans lequel les débats concernant la réduction de l'âge pénal opèrent. Après, il discute certaines hypothèses qui les soutiennent, en tissant les fils de la trame construite à la lumière des productions théorique du chercheur Angel Pino. Enfin, il élabore les considérations sur le thème soulignant les questions nucléaires et révèle les aspects idéologiques du débat, cachés sous le voile des apparences, (LEFEBVRE, 1979), par l'idéologie néolibérale.

Mots-clés: Réduction de la majorité pénale. Violence. Développement humain. La psychologie historique et culturelle.

\section{Introdução}

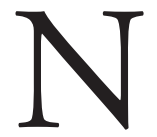

o ano de 2015, o Brasil foi visivelmente invadido por um intenso debate acerca da redução da idade penal, em razão da aprovação, na Câmara dos Deputados, da Proposta de Emenda Constitucional n. 171 de 19 de agosto de 1993. (BRASIL, 1993)

Convém mencionar que o texto da PEC 171/1993 foi aprovado em julho de 2015, sob protestos contrários à mudança constitucional, uma vez que o Presidente da Câmara na ocasião, Deputado Federal Eduardo Cunha (PMDB-RJ), realizou uma manobra regimental no sentido de colocar o tema novamente em votação um dia após a rejeição na plenária de um texto da PEC 171/1993 mais abrangente. No entanto, para que a referida proposição legislativa transforme-se em lei, e seja promulgada, é necessário que passe por mais dois turnos de votação no Senado Federal. ${ }^{1}$

A PEC 171/1993, de autoria do ex-deputado Benedito Domingos (PP-DF), que altera a redação do artigo 228 da Constituição Federal (imputabilidade penal do maior de dezesseis anos) (BRASIL, 1988), caracteriza-se como a mais antiga a tramitar no Congresso Nacional quando o assunto é versar sobre a redução da idade penal no Brasil.

O debate se insere em um contexto de divergências acirradas e segue polarizado: de um lado ecoam vozes que bradam a imputabilidade aos maiores de 
16 anos e clamam pelo confinamento dos jovens ${ }^{2}$ que cometem atos infracionais em um sistema prisional expressamente violento; e, de outro emergem, paradoxal e concomitantemente, posiçóes contrárias à aprovação da PEC 171/1993.

Nesse ínterim, movimentos sociais, organizaçóes ${ }^{3}$, especialistas e profissionais que conhecem o cerne da realidade do Sistema Socioeducativo - e dos jovens que nele cumprem as medidas que lhe são aplicáveis - ancorados em legislaçôes e em análises históricas, políticas, sociais e econômicas, articulam-se e lutam pela consolidação efetiva do Estatuto da Criança e do Adolescente (ECA), documento consonante com os direitos fundamentais reconhecidos pelas Convençóes Internacionais, pois compreendem o impacto desta nefasta manobra política que insiste em selar a epistemologia do ideário neoliberal ${ }^{4}$ e em solapar os direitos, duramente conquistados, das crianças e dos jovens à cidadania. (PINO, 1990)

Um paradoxo que perpassa o debate e alcança na realidade atual intensidade paroxísmica, pelo fato de estar evidente tanto nos pareceres favoráveis como nos pareceres contrários à redução da idade penal, é o que se refere à tese do desenvolvimento humano.

Subjacente a esta tese existe uma questão precedente que atravessa a história do pensamento ocidental, desde a Grécia antiga até a sociedade contemporânea, e que se refere à passagem da ordem da natureza à ordem da cultura e à complexa relação entre o biológico e o social na condição humana. (PINO, 2005a)

Apesar de esta questão conduzir a uma discussão que extrapola os limites de análise deste artigo, é impossível deixar de mencioná-la, uma vez que apresenta desdobramentos que afetam o modo de conceber o desenvolvimento cultural do gênero humano, pedra angular da psicologia.

Todos esses pontos instigantes que circundam o debate da redução da idade penal encontram possibilidades fecundas de problematização e avanços a partir das contribuiçóes teóricas do professor e pesquisador espanhol, naturalizado brasileiro, Angel Pino Sirgado.

Angel Pino, considerado referência intelectual nos campos da psicologia e da educação, desenvolveu estudos, com rigor científico, em distintas áreas do conhecimento, como: psicologia, educação, filosofia, sociologia, criminologia, semiótica, dentre outras, brindando-nos com um legado de obras inestimáveis e de relevância nacional e internacional.

Desde a década de 1960, Angel Pino explicitava em suas produçóes teóricas preocupação com os fenômenos sociais, de modo geral, e um engajamento ético-político na defesa dos direitos e da concretização da cidadania das crianças e dos jovens, de modo particular.

Angel Pino, ao pautar-se na perspectiva histórico-cultural em Psicologia (VIGOTSKI, 2004), a qual se fundamenta nas premissas do materialismo 
histórico e dialético na linha de Marx e Engels (2007), investigou temas caros à psicologia, como: a constituição cultural do homem, a mediação semiótica, a violência, a produção imaginária e a formação do sentido estético, dentre outras temáticas essenciais para a compreensão da condição humana.

A partir destas consideraçóes, o presente artigo objetiva sinalizar as contribuiçóes teóricas do renomado pesquisador Angel Pino para a análise dos aspectos mais significativos que emergem dos debates travados acerca da PEC 171/1993, os quais implicam compreender a essência das concepçóes de: violência, desenvolvimento humano, juventude, educação, direito social e vida humana, as quais transitam e se edificam na sociedade brasileira contemporânea.

O estudo da temática em pauta encerra grande complexidade teórico-metodológica e demanda uma investigação profunda e exaustiva. Por razóes que são óbvias, optou-se por priorizar somente os aspectos mais significativos que circunscrevem o referido debate.

Desse modo, o artigo primeiramente situa o contexto em que se inserem os embates atinentes à redução da idade penal. Na sequência, problematiza algumas das premissas que os sustentam, alinhavando os fios da trama construída à luz das produçóes teóricas basilares do pesquisador Angel Pino. Por último, tece consideraçóes sobre o tema destacando questóes nucleares e desvelando os aspectos ideológicos do debate, dissimulados, sob o véu das aparências (LEFEBVRE, 1979), pelo ideário neoliberal.

\section{O advento inexorável da PEC 171/1993}

Desde o ano de 1993 até os dias atuais mais de 26 Propostas de Emenda à Constituição (PEC's), pleiteando a redução da idade penal, foram apresentadas e passaram a tramitar na Câmara dos Deputados e no Senado Federal, seja através de pareceres de admissibilidade, seja por meio de pedidos de vista conjunta. (CÂMARA DOS DEPUTADOS, 2015)

Apesar das diversas tentativas de alteração da legislação, todas as PEC's declinaram e foram arquivadas, apensadas à PEC 171/1993, após manifestação das Comissões de Constituição e Justiça e Cidadania (CCJC) das Casas. (SOUZA; CAMPOS, 2007)

No entendimento de juristas brasileiros os artigos em defesa dos direitos da criança e do adolescente constituíam cláusulas pétreas e, como princípios constitucionais, deveriam ser preservados. (CORRÊA, 2001) Não obstante, em 2015, a PEC 171/1993 retornou à agenda política, impetuosamente, articulada a uma retórica mais encorpada pela execração, de tal forma que o processo de tramitação avançou de modo jamais visto na história da luta contra a redução da idade penal. 
Em um panorama como este, os parlamentares também passaram a analisar o Projeto de Lei n. 5385 de 16 de abril de 2013 (BRASIL, 2013) que prevê o aumento do período máximo de internação dos jovens de três para oito anos.

A questão provocou maior inquietação quando, após aprovação da PEC 171/1993 em primeira votação, o Presidente da Comissão Especial da Câmara dos Deputados designada para discutir a Proposta, Deputado Federal André Moura (PSC-SE), com a ratificação da maioria dos membros da Comissão, convidou jornalistas e apresentadores de telejornais e de programas policiais sensacionalistas para uma audiência pública sobre o tema. Adicionalmente, um cantor brasileiro foi convidado para engrossar o antológico debate. (PORTAL IMPRENSA, 2015)

Todavia, o polêmico e controverso debate sobre a redução da idade penal não caracteriza proposta exclusivista da política brasileira. Segundo Gomes (2015), diversos países têm debatido a temática: de um lado, encontram-se aqueles que posicionam-se contrariamente à medida, advertindo que as crianças e os jovens devem ser tutelados pela família, pelo Estado e pela sociedade, uma vez que, por experiência anterior, constataram que políticas de endurecimento de penas e de ampliação do encarceramento mostraram-se totalmente ineficientes (VÁSQUEZ GONZÁLEZ, 2005); de outro, situam-se aqueles que patrocinam a campanha da redução da idade penal como medida de segurança pública para excluir os jovens das classes populares do convívio da sociedade, alegando preocupação no combate à violência e defendendo a necessidade de estabelecer a imputabilidade penal aos 16 anos ou até mesmo em idade inferior a esta. (CORTE REAL; CONCEIÇÃO, 2013)

Os posicionamentos favoráveis à redução da idade penal comumente se alicerçam sob três premissas: a primeira diz respeito à conviccão de que encarcerar jovens precocemente seria a alternativa plausível para enfrentar a violência e reduzir as taxas de criminalidade no país; a segunda, refere-se ao fato de que os jovens de 16 anos podem participar do processo de decisão eleitoral manifestando-se por meio do voto sobre os rumos da política do país, então, têm consciência de seus atos e podem ser considerados imputáveis, ou seja, responsabilizados penalmente; e, a terceira, concerne à noção de que, se a realidade social muda, o jovem não é o mesmo de décadas atrás e, portanto, as normas jurídicas devem estar em consonância com essas transformaçóes. (BRASIL, 1993)

\section{A realidade escancarada}

O Fundo das Naçóes Unidas para a Infância (Unicef) ao declarar-se contra a reduçáo da idade penal durante o mandato de acompanhamento da implementação da Convenção sobre os Direitos da Criança da Organização 
das Naçóes Unidas (ONU), da qual o Brasil é signatário, asseverou que dos 21 milhóes de adolescentes brasileiros, apenas $0,013 \%$ cometeu atos contra a vida. ${ }^{5}$ (BORGES; CANO, 2014)

O Unicef divulgou, ainda, dados que denotam uma realidade que adquire contornos dramáticos: os homicícios são a causa de $36,5 \%$ das mortes de adolescentes, enquanto para a população em geral esse tipo de morte representa 4,8\% do total. Entre 2006 e 2012 pelo menos menos 33 mil adolescentes entre 12 e 18 anos foram assassinados no Brasil. (BORGES; CANO, 2014) Estes índices elevam-no à posição de segundo país no mundo em número absoluto de homicídios de adolescentes, ficando atrás somente da Nigéria. (UNICEF, 2014) Destaca-se, ainda, que a violência homicida se concentra, especialmente, em adolescentes e jovens negros e pobres. (UNICEF, 2014) Diante desse quadro, vê-se que não são "os adolescentes e jovens" os principais autores da violência, mas as vítimas de um extermínio cotidiano.

A partir dessas consideraçóes, constata-se que a experiência da violência extrema é parte da vivência diária dos jovens brasileiros. Em um país marcado pela desigualdade social e pelo não reconhecimento dos direitos básicos à cidadania - moradia, alimentação, assistência médica, educação, trabalho, saneamento, segurança e justiça social (PINO, 2002) - é inadmissível exigir precisamente da população mais discriminada e majoritariamente privada dessas condiçóes, à qual é negada a apropriação, de fato, dos bens materiais e culturais produzidos socialmente, o ônus pelas mazelas sociais.

De acordo com Marx e Engels (2007, p. 50) “[...] a primeira premissa de toda a existência humana, e, portanto, também de toda a história, é a premissa de que os homens, para fazer história, se achem em condiçóes de poder viver [...]”.

Isso posto, buscar saídas para a violência tratando o problema como uma questão meramente judiciária, ao promover alterações legislativas que prescrevem a redução da idade penal, significa submeter os jovens das classes populares a uma situação de precariedade ainda mais cruel movida pela lógica do encarceramento.

Conforme observou Pino (1987), pobreza não é sinônimo de irresponsabilidade moral, como riqueza não o é de responsabilidade. Assim, "[...] o que para algumas classes sociais é um caso doméstico para outras torna-se um caso social [...]”. (PINO, 1987, p. 42) A condição de classe confere ao indivíduo uma significação social desigual. Logo, não é difícil antever um futuro, se é assim que se pode chamar, notoriamente previsível a esses jovens: o arremesso em sua grande maioria em um sistema penitenciário que se delineia de maneira brutal e degradante. 


\section{Um quadro sem retoques}

Da discussão empreendida, decorre a necessidade de assinalar brevemente alguns aspectos atuais que configuram o sistema penitenciário brasileiro.

De acordo com o censo realizado pelo Conselho Nacional de Justiça (CNJ), em 2014, o Brasil registrou 711.463 presos, incluindo nessa estatística indivíduos em prisão domiciliar. Estes números elevaram o Brasil à terceira maior população carcerária do mundo, deixando-o atrás somente de países como a China, com 1,7 milhão, e os Estados Unidos, com 2,2 milhóes. (CONSELHO NACIONAL DE JUSTIÇA, 2014)

Segundo o CNJ (2014) a população carcerária no Brasil cresceu exponencialmente, mais de $400 \%$ em 20 anos, sem que houvesse um aumento proporcional do número de vagas. Dessa maneira, os estabelecimentos prisionais, no Brasil, apresentaram um déficit de 354 mil vagas. (CONSELHO NACIONAL DE JUSTIÇA, 2014)

Acrescenta-se à leitura social destes indicadores um dado alarmante, divulgado pelo International Centre for Prison Studies (ICPS): enquanto a média mundial de encarceramento é de 144 presos para cada 100 mil habitantes, no Brasil esse número eleva-se para 300. (WALMSLEY, R., 2014)

Um relatório publicado pela Anistia Internacional, em fevereiro de 2015, revela ainda que a corrupção, a tortura, a superlotaçáo extrema, as condiçóes subumanas nas unidades prisionais e a reincidência $(7$ a cada 10 presos voltam a cometer crimes), constituem fatores reiteradamente inquietantes. (ANISTIA INTERNACIONAL, 2015)

Desse modo, é definitivamente impensável que os atuais presídios brasileiros, que não atendem adequadamente a população que lhes é cabível por lei e não propiciam as ínfimas perspectivas de vida, sejam capazes de receber os jovens que praticam atos infracionais, tal como sinaliza a PEC 171/1993.

Outro equívoco manifesto no debate, que atravessa o Congresso e a sociedade civil, refere-se à pretensa impunidade presente na legislaçáo brasileira ao estabelecer a inimputabilidade penal aos jovens com idade inferior a 18 anos que tenham praticado ato infracional.

$\mathrm{Na}$ esteira dessa discussão, faz-se imprescindível considerar que embora a Constituição Federal do Brasil (BRASIL, 1988), o Código Penal (BRASIL, 1940) e o Estatuto da Criança e do Adolescente (BRASIL, 1990) compactuem, por razóes de política criminal com a inimputabilidade penal, em sentido adverso ao que preconiza o senso comum e a mídia sensacionalista, a responsabilização pelo ato infracional está prevista no ECA (1990), compreendendo o período de 12 
a 18 anos em condiçóes especiais (medidas socioeducativas) e, excepcionalmente, estendendo tais condições em casos de jovens maiores de 18 anos, os quais eram inimputáveis na época em que praticaram o ato infracional. Nessa situação, as condiçóes diferenciadas cessam de modo obrigatório quando o jovem completa 21 anos.

As medidas de cunho socioeducativo são prescritas em níveis distintos de equidade que vão da advertência à inserção em regime de semiliberdade ou internação em estabelecimento educacional, conforme disposto nos incisos do art. 112 do ECA. (BRASIL, 1990) Portanto, inimputabilidade não significa, de modo algum, impunidade.

Nessa dimensão, os argumentos que asseveram que o Código Penal brasileiro é desatualizado em face de outros países, pelo fato de supostamente serem mais rigorosos com a idade penal na esfera jurídico-legal (CARVALHO, 2015), soam desfocados não apenas por dissimular a distinção existente entre a idade da responsabilidade juvenil e a idade para a maioridade penal, mas também pelo fato de que a equiparação com os ordenamentos jurídicos de outros Estados ignora as condiçóes objetivas da realidade histórica e social de um país. (MARX, 2004)

Cabe frisar que "o crime não é privilégio de classes como o é a impunidade”. (SIRGADO, 1980, p, 58) Fatos concretos que envolvem diretamente os "crimes de colarinho branco" estão ao conhecimento de todos, não sendo necessário relembrá-los. (PINO, 2007, p. 768)

É notório que o argumento da impunidade proferido pela campanha em favor da redução da idade penal, na moral laica da era contemporânea, “[...] nada mais é que o jogo da moral imoral ou de uma imoralidade que se oculta por trás da aparência da moralidade (grifo do autor) [...]”. (PINO, 2007, p. 780)

\section{A PEC 171/1993 e o paradoxo da condição humana}

Outra premissa que sustenta o debate sobre a redução da idade penal conduz a análise de excertos que compóem a justificação da PEC 171/1993. (BRASIL, 1993) À primeira vista, essa justificação provoca estranheza, até mesmo nos leitores mais desavisados, principalmente, ao considerar os princípios de um Estado laico como, ao menos se define, o Brasil.

Os argumentos que a fomentam, nitidamente, não denotam pesquisas consistentes ou evidências científicas, mas posicionamentos valorativos biologicistas e passagens bíblicas que enaltecem preceitos de teor religioso e doutrinas da fé, ao invés de argumentos jurídicos e análises da totalidade concreta. (LUKÁCS, 1967; MARX, 2011) 
[...] A uma certa altura, no Velho Testamento, o profeta Ezequiel nos dá a perfeita dimensão do que seja a responsabilidade penal. Não se cogita nem sequer de idade: A alma que pecar, essa morrerá.

[...] Ainda referindo-nos a informaçóes bíblicas, Davi, jovem modesto pastor de ovelhas acusa um potencial admirável com o seu estro de poeta e cantor dedilhando a sua harpa mas, ao mesmo tempo, responsável suficientemente para atacar o inimigo do seu rebanho. Quando o povo de Deus estava sendo insultado pelo gigante Golias, comparou-o ao urso e ao leão que matara com suas mãos.

[...] Salomão, do alto de sua sabedoria, dizia: Ensina a criança no caminho em que deve andar, e ainda quando for velha não se desviará dele (grifos do autor). (BRASIL, 1993, p. 23063-23064)

Para além do universo idealista e transcendental os defensores da PEC 171/1993, ao criticarem o caráter biológico no que tange ao recorte etário para a responsabilização penal presente nos documentos legislativos brasileiros, ancoram-se no mesmo modelo de análise biologicista, eivado pelo determinismo mecanicista, o qual pretendem combater. A inversão do discurso é nítida e se consolida através de proposiçóes fetichizadas (MARX, 2007):

A conceituação de inimputabilidade penal, no direito brasileiro, tem como fundamento básico a presunção legal de menoridade, e seus efeitos, na fixação da capacidade para entendimento do ato delituoso. Por isso o critério adotado para essa avaliaçáa atualmente é o biológico. Ao aferir-se esse grau de entendimento do menor, tem-se como valor maior a sua idade, pouco importando o seu desenvolvimento mental.

[...] Nos grandes centros urbanos, os adolescentes entre dezesseis e dezoito anos já possuem, indiscutivelmente, um suficiente desenvolvimento psíquico e a plena possibilidade de entendimento $[\ldots]$

[...] Nessa faixa de idade já estão sendo criados os fatores que marcam a identidade pessoal. Surgem as possibilidades para a execução do trabalho disciplinado. (BRASIL, 1993, p. 2306223063)

As assertivas embasadas no obscurantismo religioso e no modelo biologicista fazem parte de um artifício ideológico, que dissolve antagonismos filosóficos, políticos, sociais e econômicos, adequado aos interesses do capitalismo monopolista contemporâneo, traduzidos pelo ideário neoliberal. O modelo biolo- 
gicista caracteriza-se pela naturalização do social o qual impede a compreensão do desenvolvimento cultural do gênero humano. (VIGOTSKI, 1995)

Faz-se imperioso, entretanto, um alerta: não basta reconhecer que o desenvolvimento individual deva ser analisado no contexto da vida social, uma vez que o viés biologicista pode se fazer presente no modo de analisar as relaçóes entre indivíduo e sociedade. O eixo central da crítica não é meramente a ausência do social, mas o fato de que esse social é concebido como algo que não está na constituição da própria essência da individualidade, como elemento extrínseco a ela. (VIGOTSKI, 1995)

Essa concepção de desenvolvimento humano compartilha o mesmo pressuposto fundamental que polariza o individual e o social, o biológico e o cultural, como se uma categoria fosse independente e estranha à outra. (VIGOTSKI, 1993)

Destarte, o maior desafio está em superar o dualismo e, à uma concepção naturalista de desenvolvimento humano, contrapor uma concepção materialista histórica e dialética (VIGOTSKI, 1987), afinal, a sociedade humana é regida por leis históricas, e não por mecanismos naturais ou biológicos. (PINO, 2000) Neste sentido, afirmar que "[...] o desenvolvimento humano é cultural equivale, portanto, a dizer que é histórico, ou seja, traduz o longo processo de transformação que o homem opera na natureza e nele mesmo como parte dessa natureza [...]”. (PINO, 2000, p. 51)

O homem é um ser cuja condição humana se concretiza sob o ineliminável substrato biológico e o trabalho (MARX, 2013) constitui o eixo principal na análise do desenvolvimento cultural do homem. Esse princípio encontra sustentação no seguinte raciocínio:

a) se o desenvolvimento humano é de natureza cultural, b) e se a cultura não é obra da natureza mas do próprio homem, o qual é, ao mesmo tempo, produtor e produto dela; c) então o desenvolvimento cultural deve ter um começo que não pode ser confundido com o nascimento biológico, pois este é condição da concretização daquele, mas não razão suficiente de sua existência. (PINO, 2005, p. 33)

Nesta perspectiva, o desenvolvimento cultural do homem somente pode ser compreendido como processo em constituição e, em contradição, fundado no salto qualitativo entre natureza e cultura, entre biológico e social (PINO, 2005), como luta interna, como drama. (VIGOTSKI, 2000)

Em suma, as assertivas constantes na PEC 171/1993 de que "[...] os adolescentes entre dezesseis e dezoito anos já possuem um suficiente desenvol- 
vimento psíquico e a plena possibilidade de entendimento" [...] e, ainda, de que "[...] nessa faixa de idade já estão sendo criados os fatores que marcam a identidade pessoal [...]", indiscutivelmente, colocam interrogaçóes que constituem pontos de referência para delinear a concepção de desenvolvimento humano que fundamenta a referida proposta.

É fato que recortes etários são utilizados para fins legais, jurídicos, escolares. Todavia, faz-se premente compreender que o desenvolvimento cultural do homem jamais se encerra em um processo que prima pela fixidez ou que é instituído por critérios estritamente biológicos, cronológicos e que denotam um padrão típico ou um fenômeno universal. Paradoxalmente, as peculiaridades do desenvolvimento humano se edificam nas contradiçóes da cultura, nos embates das classes sociais e na diversidade das condiçóes sociais, históricas e econômicas que permeiam a constituição das distintas infâncias e juventudes.

É indelével, portanto, o fato de que as leis naturais (biológicas) e as leis históricas (culturais) amalgamam-se de tal maneira na história pessoal (de natureza social) de cada indivíduo que qualquer tentativa de separação é decerto impensável. (PINO, 2005)

\section{Considerações finais}

Após perfazer a breve trajetória crítico-analítica neste artigo, nota-se que o debate sobre a reduçáo da idade penal se insere no campo das propostas de enfrentamento à violência.

Em um cenário de tensão social diante do fenômeno, a mídia brasileira declara-se notadamente favorável à redução da idade penal. A exposição excessiva de casos emblemáticos que envolvem violência, e cujos autores são jovens com idade inferior a 18 anos, incita grande parte da população, temerária em relação ao aumento da violência e expropriada de uma análise crítica sobre o tema, a proferir, de forma imediatista, discursos intransigentes que chancelam levianamente a campanha legislativa em favor da redução da idade penal e das políticas de ampliação e recrudescimento das penas e do encarceramento.

No que diz respeito à violência, cabe enfatizar prioritariamente dois aspectos: o primeiro, de caráter espaço-temporal, é que a violência não é um fenômeno específico do mundo contemporâneo e dos espaços urbanos, uma vez que está presente indistintamente em todas as civilizações, períodos históricos e classes sociais. (SANTOS, 2015) "O corolário dessa proposição é que a violência não é da ordem da natureza; é da ordem da cultura, pelo fato de fazer parte da história social construída e transformada pelo homem [...]”. (SANTOS, 2015, p. 186) 
O segundo aspecto, de natureza conceitual, é que a violência, por ser um fenômeno que pertence à ordem da cultura, implica racionalidade e intencionalidade. E, ao ir além da violação das leis e dos limites admisssíveis pela sociedade, traduz no mundo contemporâneo a réplica da secular exclusão social, das condiçôes de miséria humana e das ínfimas possibilidades de vida a que milhóes de crianças e jovens estão brutalmente submetidos. (SANTOS, 2014) Compreende-se, então, que a violência altera a qualidade de uma relação inaugurando um quadro inteiramente distinto das relaçóes humanas.

Sob esse prisma, encontrar modos de enfrentar a violência requer uma análise profunda do fenômeno (PINO, 1995, 2007) e não medidas inócuas, no âmbito judiciário, que envolvem o recrudescimento das penas e a ampliação de um sistema carcerário violento, degradante e desumano.

Para enfrentar a violência "[...] não basta a repressão e a reclusão de seus autores ou, pior ainda, o seu extermínio [...]”. (PINO, 2007, p. 779) A violência é um problema social e não jurídico. Por conseguinte, a imputabilidade penal aos jovens em idade inferior a 18 anos não é a resposta consentânea para o fenômeno da violência.

Com efeito, convém sublinhar: a PEC 171/1993 é revestida de simulacro, possui caráter demagógico e eleitoreiro e, ainda, legitima políticas de açóes focalizadas, precarizadas e passíveis de clientelismo. Os seus enunciados pragmatistas, reiteradamente opressores, expressam total desacordo com o ECA, documento que, segundo Pino (1990), representa um gesto político de reconhecimento do Estado do direito das crianças e dos jovens à cidadania independente da classe social de origem.

Na visão de Pino (1990), a imprescindibilidade desse documento não está na promulgação da lei propriamente dita, "[...] fato banal num país tão inflacionado em material legal [...]”. (PINO, 1990, p. 61), mas está na significação política e jurídica dessa lei.

Nesse sentido, a discriminação e a repressão, "[...] fundadas no preconceito da inferioridade das classes populares e da sua tendência natural à desordem social, o que justifica as medidas preventivas e de controle social de que elas são objeto[...]”. (PINO, 1990, p. 62), devem ser encaradas como um problema social cujo enfrentamento envolve o conjunto da sociedade na luta pela implementação de políticas públicas que garantam, de fato, às crianças e aos jovens o reconhecimento e o cumprimento dos direitos constitucionais. Nessa linha de argumentação, o princípio da igualdade de direitos é uma conquista histórica que não pode se perder na "letra fria da lei". (PINO, 1990, p. 78)

Contudo, segundo Mészáros (2003, 2007), a igualdade de direitos real, substantiva, radical, capaz de revolucionar o modo de viver do ser humano somente advirá quando o proletariado conscientizar-se, a partir do conhecimento 
de si, como classe social, e das condiçôes históricas objetivas (LUKÁCS, 2003) que o oposto da igualdade não é a diferença, mas a desigualdade que lhe é imputada cotidianamente.

Segue-se dessa breve análise que, ao desvendar a concepção de desenvolvimento humano que sustenta a PEC 171/1993, ressonâncias históricas de uma realidade de exclusão social tornam-se evidentes.

O foco da PEC 171/1993 sobre pontos exíguos caracteriza, incontestavelmente, uma estratégia que vislumbra dissuadir uma questão preliminar: o enclausuramento e a aniquilação de uma classe social considerada indesejável e que desempenha (quando ainda lhe é possível) as tarefas de mais ínfimo valor social.

De forma geral, Pino (2005, p. 268), ao conceber o desenvolvimento cultural do homem, reitera que "[...] se a natureza precede a cultura e a cultura supóe a natureza - porque ela é, em última instância, a própria natureza transformada, ou seja, uma natureza que, sem deixar de ser natureza, torna-se algo novo... uma natureza humanizada [...]", então, o desenvolvimento cultural do gênero humano não é, no sentido estrito do termo, impedido de ocorrer. O que está em jogo, isso é inegável, é o fato de que esse desenvolvimento diante da ausência de acesso aos bens materiais sobrevirá face às injustiças sociais, à resignação, à indignação, à resistência e à desistência da vida, muitas vezes não declarada e duramente silenciada.

Ora, se as crianças e os jovens que vivem em situação de pobreza extrema têm seus direitos mais que negados, ignorados pela sociedade, como é possível pressupor percursos de desenvolvimento humano com vistas à construção de um 'ideal de cidadania'? Como conjecturar que crianças e jovens estigmatizados das mais distintas formas possam agir de acordo com os princípios de valorização da vida, de justiça social e do direito à propriedade se estas noçóes não fazem parte de suas vivências?

Conforme Pino (2005, p. 153) brilhantemente assevera, é difícil imaginar que no Brasil contemporâneo um número excessivo de crianças e jovens veem sua dignidade e seus direitos serem 'pisados' justamente pela mesma sociedade que os proclama.

Assim, o processo de desenvolvimento cultural do homem é consubstanciado inextricavelmente às contradiçóes e à busca incessante por modos de constituir-se humano entre um modelo que é imposto pela hegemonia neoliberal e uma realidade crassa que ignora esse processo de desenvolvimento em condiçóes dignas de existência.

De forma bastante plausível, Pino (2005) ressalta, ainda, que privar crianças e jovens do acesso aos seus direitos básicos, coloca em alto risco sua rea- 
lização como pessoa humana, afinal "[...] as características humanas não fazem parte do que o homem tem, mas do que ele é. Neste ponto, o humano não se conjuga com o verbo ter, mas com o verbo ser". (PINO, 2005, p. 156)

Em última análise, cumpre destacar que os distintos excertos da PEC $171 / 1993$ e apensadas, sob a égide da Lei, colocam inexoravelmente em risco os rumos políticos do país.

A história secular das práticas arbitrárias de internação e confinamento mostra que o discurso preponderante propalado nos centros do poder político referendado, não nos esqueçamos, pela sociedade (PINO, 2007) e que pleiteia a redução da idade penal -, está coroado de proposições inspiradas em uma lógica retributiva revestida por um ímpeto penalizante. Estas proposiçôes coadunam com práticas classistas, racistas e repressivas da época do insólito Código dos Menores (BRASIL, 1979), com vistas à limpeza social e ao controle dos segmentos de mais baixa renda das classes populares. (PINO, 1989)

Se o debate sobre a redução da idade penal levanta a questão do significado da infância e da juventude na sociedade contemporânea e do lugar que nela é reservado às crianças e aos jovens das classes populares (PINO, 1987), também indaga sobre qual caminho a "corrida" para a aprovação da PEC 171/1993 conduzirá a Nação.

O Brasil está em um tempo de definições e o perigo é iminente. A PEC $171 / 1993$, se aprovada, pode abrir precedentes e impactar diversas áreas da legislação brasileira.

Sabe-se que a reticência quanto à possibilidade de alteração do cenário político deve-se à imposição de proposiçóes e ações afinadas ao ideário neoliberal. Sabe-se também que a "equação do tempo" não é simples e que o tempo que foi, não volta.

Então, ao seguir as preleçóes de Marx (2010) e ir na contracorrente do niilismo e da máxima contida nos anéis do Rei Salomão: "Tudo passará" (TARKOVSKI, 1990), conclamo a todos aqueles que lutam pelos direitos das crianças e dos jovens à uma vida digna, e faço o alerta: "A vivência do tempo não é viver no tempo, mas fazer do tempo vida [...]”. (PINO, 2005b, p. 60)

\section{Notas}

1. No Brasil, para que uma proposição legislativa tranforme-se em norma jurídica é necessário que passe por dois turnos de votação em cada uma das Casas do Congresso Nacional, a Câmara dos Deputados e o Senado Federal e obtenha voto favorável de três quintos dos membros das distintas Casas. Cumpre lembrar que toda proposição também deve ser analisada, obrigatoriamente, pela Comissão de Constituição de Justiça e Cidadania - CCJC para saber se se adequa aos princípios de constitucionalidade. 
2. Cabe interpor um parêntese no sentido de explicitar que, face à complexidade que envolve a conceituação e a categorização etária referentes aos termos adolescente e jovem no Brasil (SILVA; LOPES, 2009), optou-se pelo uso, ao longo do texto, do termo jovem, como processo de vivência (VIGOTSKI, 1999, 2010) que se situa entre a infância e a vida adulta, respeitando, entretanto, a acepção e o recorte etário determinados nos documentos da UNICEF; no Estatuto da Criança e do Adolescente (BRASIL,1990), o qual considera adolescente a pessoa entre 12 e 18 anos de idade; e no Estatuto da Juventude (BRASIL, 2013), o qual dispóe que são considerados jovens as pessoas com idade entre 15 e 29 anos de idade.

3. Diversas entidades em resposta à sociedade criaram o Movimento 18 Razóes para a náo redução da maioridade penal. (MOVIMENTO 18 RAZÓES, 2015)

4. Compreende-se que a teoria de Friedrich Hayek, um dos maiores expoentes da Escola Austríaca, representa o marco no fundamentalismo neoliberal. A obra $O$ caminho da servidão (HAYEK, 2010) pode ser considerada a referência principal para forjar a doutrina liberal dos séculos XVIII e XIX sobre nova roupagem (a neoliberal).

5. Estimativa divulgada pelo Unicef Brasil com base no levantamento realizado pelo Sistema Nacional de Atendimento Socioeducativo (Sinase) e pela Pesquisa Nacional por Amostra de Domicílios (Pnad) do Instituto Brasileiro de Geografia e Estatística (IBGE), em 2012.

\section{Referências}

ANISTIA INTERNACIONAL. Anistia Internacional Informe 2014/2015. Rio de Janeiro, 2015. Disponível em: <https://anistia.org.br/wp-content/uploads/2015/02/Web-Informe-2015-03-06-final.pdf >. Acesso em: 1 jun. 2015.

BORGES, D.; CANO, I. Indice de homicídios na adolescência no Brasil. Rio de Janeiro: Secretaria de Direitos Humanos da Presidência da República/Unicef/Observatório das Favelas, 2014. Disponível em: <http://www.unicef.org/brazil/pt/br IHA2012.pdf>. Acesso em: 1 jun. 2015.

BRASIL. Lei n. 6697, de 10 de outubro de 1979. Institui o Código de Menores. Brasília, DF, Diário Oficial da Uniáo, 11 out. 1979. Disponível em: <http://www.planalto.gov.br/ Ccivil 03/leis/1970-1979/L6697.htm>. Acesso em: 1 jun. 2015.

. Decreto-Lei n. 2848, de 7 de dezembro de 1940. Código Penal. Diário Oficial da Uniáo, 31 dez. 1940. Disponível em: <http://www.planalto.gov.br/ccivil 03/decreto-lei/Del2848compilado.htm>. Acesso em: 2 jun. 2015.

Constituição (1988). Constituiçáo da República Federativa do Brasil. Brasília, DF: Senado Federal, 1988. Disponível em: <http://www.planalto.gov.br/ccivil 03/constituicao/constituicao.htm>. Acesso em: 4 abr. 2015.

Lei n. 8069, de 13 de julho de 1990. Dispóe sobre o Estatuto da Criança e do Adolescente e dá outras providências. Brasília, DF, Diário Oficial da União, 16 jul. 1990. Disponível em: <http://www.planalto.gov.br/ccivil 03/Leis/18069.htm>. Acesso em: 4 abr. 2015 .

Lei n. 12852, de 05 de agosto de 2013. Institui o Estatuto da Juventude e dispóe sobre os direitos dos jovens, os princípios e diretrizes das políticas públicas de juventude e o 
Sistema Nacional de Juventude - SINAJUVE. Brasília, DF., Diário Oficial da Uniáo, 06 ago. 2013. Disponível em: <http://www.planalto.gov.br/ccivil 03/ Ato2011-2014/2013/ Lei/L12852.htm>. Acesso em: 4 jun. 2015.

BRASIL. Projeto de Emenda à Constituição n. 171, de 19 de agosto de 1993. Altera a redaçáo do artigo 228 da Constituição Federal (imputabilidade penal do maior de dezesseis anos). Brasília, DF., Diário Oficial da Uniáo, ano XLVIII, n. 179, p. 2306223065, 27 out. 1993. Disponível em: <http://Imagem.camara.gov.br/Imagem/d/pdf/ DCD27OUT1993.pdf\#page=10>. Acesso em: 29 mai. 2015.

. Projeto de Lei 5385, de 16 de abril de 2013. Altera o Decreto-Lei n. 2848, de 7 de dezembro de 1940 (Código Penal) e as Leis n. 8069, de 13 de julho de 1990 (Estatuto da Criança e do Adolescente), e n. 12594, de 18 de janeiro de 2012 (SINASE). Disponível em: <http://www2.camara.leg.br/proposicoesWeb/fichadetramitacao?idPropo sicao $=572144>$. Acesso em: 28 mai. 2015.

CÂMARA DOS DEPUTADOS. Projeto de Lei e outras Proposiçóes. Desenvolvida pela Camâra dos Deputados, Brasília, DF. Disponível em: <http://www2.camara.leg.br $>$. Acesso em: 4 abr. 2015.

CARVALHO, L. G. B. A reduçáo da maioridade penal: 16 anos. Disponibilizada por JusBrasil. Disponível em: <http://tj-pi.jusbrasil.com.br/noticias/100449428/a-reducao-da-maioridade-penal-16-anos>. Acesso em: 2 jun. 2015.

CONSELHO NACIONAL DE JUSTIÇA. CNJ divulga dados sobre nova populaçáo carcerária brasileira. Brasília, DF., 5 jun. 2014. Disponível em: <http://www.cnj.jus. br/noticias/cnj/61762-cnj-divulga-dados-sobre-nova-populacao-carceraria-brasileira $>$. Acesso em: 31 mai. 2015.

CORRÊA, M. M. S. Redução da idade de imputabilidade penal - aspectos constitucionais. In: BULHÕES, A. N. A. (Org.). A razão da idade: mitos e verdades. Brasília, DF: MJ/SEDH/DCA, 2001, p. 24-29.

CORTE REAL, F. G. V.; CONCEIÇÃO, M. I. G. Representaçôes sociais de parlamentares brasileiros sobre a redução da maioridade penal. Psicologia: Ciência e Profissáo, Brasília, v. 33, n. 3, p. 656-671, 2013.

GOMES, K. Brasil vai na contramão mundial ao debater redução da idade penal. Deutsche Welle, Brasil, 24 abr. 2015. Disponível em: <http://www.dw.de/brasil-vai-na-contramão-mundial-ao-debater-redução-da-idade-penal/a-18394434 >. Acesso em: 1 jun. 2015.

HAYEK, F. A. O caminho da servidão. 6. ed. São Paulo: Instituto Ludwig von Mises Brasil, 2010.

LEFEBVRE, H. Lógica formal, lógica dialética. 2. ed. Rio de Janeiro: Civilização Brasileira, 1979.

LUKÁCS, G. Existencialismo ou marxismo. São Paulo: Senzala, 1967.

. História e consciência de classe. São Paulo: Martins Fontes, 2003.

MARX, K. Manuscritos económicos-filosóficos. São Paulo: Boitempo, 2004. 
MARX, K. Crítica da Filosofia do Direito de Hegel. São Paulo: Boitempo, 2010.

. Grundrisse manuscritos econômicos de 1857-1858. São Paulo: Boitempo, 2011.

. O capital: crítica da economia política. 22. ed. São Paulo: Boitempo, 2013. v. 1.

MARX, K.; ENGELS, F. A ideologia alemã. Rio de Janeiro: Civilização Brasileira, 2007.

MÉSZÁROS, I. O século XXI: socialismo ou barbárie? São Paulo: Boitempo, 2003.

. A educação para além do capital. São Paulo: Boitempo, 2005.

. O desafio e o fardo do tempo histórico. São Paulo: Boitempo, 2007.

MOVIMENTO 18 RAZÓES PARA A NÁO REDUÇÃO DA MAIORIDADE PENAL. Movimento CONTRA a Reduçáo da Maioridade Penal. Disponível em: <https://18razoes.wordpress.com/quem-somos/>. Acesso em: 29 mai. 2015.

PINO, A. A questão do menor e o significado da infância na sociedade burguesa. Educ. Soc., Campinas, ano IX, n. 28, p. 32-50, dez. 1987.

. Política de promoção social e exercício da cidadania - uma crítica às práticas de confinamento e pobreza. Serviço Social \& Sociedade, São Paulo, ano X, n. 31, p. 141-159, set.-dez. 1989.

. Direitos e realidade social da criança no Brasil: a propósito do Estatuto da Criança e do Adolescente. Educ. Soc., Campinas, ano XI, n. 36, p. 61-79, ago. 1990.

.Violence in schools in Brazil. Thresholds in Education, USA, v. XXI, n. 2, p. 11-17, may. 1995 .

. O social e o cultural na obra de Lev S. Vigotski. Educ. Soc., Campinas, ano XXI, n. 71, p. 45-78, jul. 2000.

. Prefácio: violência, racionalidade e ordem social. In: SANTOS, S. D. M. Sinais dos tempos: marcas da violência na escola. Campinas, SP: Autores Associados, 2002.

. As marcas do humano: às origens da constituição cultural da criança na perspectiva de Lev S. Vigotski. São Paulo: Cortez, 2005a.

. Tempo real, tempo vivido, representaçôes do tempo. In: ROSSI, V. L. S.; ZAMBONI, E. Quanto tempo o tempo tem! 2. ed. Campinas, SP: Alínea, 2005b.

. Violência, educação e sociedade: um olhar sobre o Brasil contemporâneo. Educ. Soc., Campinas, v. 28, n. 100 - Especial, p.763-785, out. 2007.

PORTAL IMPRENSA. Câmara convida jornalistas para debater sobre a reduçáo da maioridade penal. São Paulo, 30 abr. 2015. Disponível em: < http://www.portalimprensa. com.br/noticias/brasil/72049/camara+convida+jornalistas+para+debater+sobre+a+reduca o+da+maioridade+penal >. Acesso: 4 mai. 2015.

SANTOS, S. D. M. Expressóes da violência na escola: rupturas e desafios em debate. Fronteiras: Journal of Social, Technological and Environmental Science, v. 3, n. 3 (Especial CIAIQ), p. 62-79, jul./dez. 2014. 
SANTOS, S. D. M. Retratos do cotidiano escolar: violência, linguagem e exclusão social. In: HUR, D. H.; LACERDA JÚNIOR, F.; RESENDE, M. R. S. (Orgs.). Psicologia e transformação: intervençôes e debates contemporâneos. Goiânia: UFG, 2015.

SILVA, C. R.; LOPES, R. E. Adolescência e juventude: entre conceitos e políticas públicas. Cadernos de Terapia Ocupacional da UFSCar, São Carlos, v.17, n. 2, p. 87-106, jul./ dez. 2009.

SIRGADO, A. P. Uma pedagogia para o menor marginalizado. Educ. Soc., Campinas, ano II, n. 5, p. 47-61, jan. 1980.

SOUZA, L. A.; CAMPOS, M. S. Redução da maioridade penal: uma análise dos projetos que tramitam na Câmara dos Deputados. Revista Ultima Ratio, ano 1, n. 1, p. 231-258, 2007.

TARKOVSKI, A. Esculpir o tempo. São Paulo: Martins Fontes, 1990.

UNICEF. Hidden in plain sight: a statistical analysis of violence against children. New York: Unicef, 2014. Disponível em: <http://www.unicef.org/publications/index 74865. html>. Acesso em: 1 jun. 2015.

VIGOTSKI, L. S. Obras Escogidas, tomo II. Madri: Visor e Mec, 1993.

. Obras Escogidas, tomo III. Madri: Visor e Mec, 1995.

. A tragédia de Hamlet, príncipe da Dinamarca. São Paulo: Martins Fontes, 1999.

. Psicologia concreta do homem (Manuscrito de 1929). Educ. Soc., Campinas, ano XXI, n. 71, p. 23-44, jul. 2000.

. Teoria e método em Psicologia. São Paulo: Martins Fontes, 2004.

. Quarta aula: a questáo do meio na pedologia. Psicologia USP, São Paulo, v. 21, n. 4, p. 681-701, 2010.

VÁSQUEZ-GONZÁLEZ, C. Derecho penal juvenil europeo. Madrid: Dykinson, 2005.

WALMSLEY, R. World Pre-trial/Remand Imprisonment List. 2nd edition. ICPS: University of Essex, London, 2014. Disponível em: <http://www.prisonstudies.org/resources/ world-pre-trialremand-imprisonment-list-2nd-edition>. Acesso em: 20 mai. 2015.

Recebido em 08 de agosto de 2015.

Aprovado em 23 de outubro de 2015.

DOI: http://dx.doi.org/10.1590/ES0101-73302015153424 